\title{
EDITORIAL
}

\section{An introduction to the sugar code}

\author{
Hans-Joachim Gabius ${ }^{1}$ Jürgen Roth $^{2}$
}

Accepted: 23 November 2016 / Published online: 14 December 2016

(C) Springer-Verlag Berlin Heidelberg 2016

\begin{abstract}
Carbohydrates have physiological importance far beyond their roles as source of energy (glycolysis) and activated hydrogen for synthesis (pentosephosphate pathway) or as constituent of the backbone of nucleic acids and of cell wall polysaccharides. The extent of compositional and structural variability of their oligomers (glycans) is unsurpassed in Nature due to the unique property of independently combining the following parameters with sequence: anomeric status, linkage positions, ring size, addition of branches and site-specific introduction of substitutions. The monosaccharides (letters of the third alphabet of life) thus generate 'words' (signals) of high-density coding capacity. These 'words' are part of the glycans on proteins and lipids, and the glycome represented by these 'words' in their entirety has cell type-dependent features. The often limited intramolecular flexibility of oligosaccharides along with an abundance of contact points for intermolecular interactions is ideal for binding processes. Glycan-based 'words' can thus be 'read,' and their message translated into cellular effects by receptors called lectins. This journal's special issue covers central aspects of the concept of the sugar code.
\end{abstract}

Keywords Glycolipid · Glycoprotein · Glycosylation • Lectin $\cdot$ Sialylation

Hans-Joachim Gabius

gabius@tiph.vetmed.uni-muenchen.de

1 Faculty of Veterinary Medicine, Institute of Physiological Chemistry, Ludwig-Maximilians-University Munich, 80539 Munich, Germany

2 Division of Cell and Molecular Pathology, University of Zurich, 8091 Zurich, Switzerland

\section{Background}

The concept of biological information and its translation into cellular effects is commonly seen as solely embodied by the genetic code. Complementarity between base pairs of nucleotides is the molecular basis for accurately copying templates and hereby starting the flow of biological information (Fig. 1, top). 'Code words' established by 'letters' of the two alphabets of life, i.e., nucleotides and amino acids, are set in direct relation by the genetic code, and the sequence of the building blocks of each type of oligo- or polymer, i.e., nucleic acids and proteins, completely defines the 'message.' As can be deduced from Fig. 2a, b, there are recurring molecular mechanisms for letting the chain of these biopolymers grow, either by phosphodiesters or by peptide bonds.

The situation for coding on the cell surface is different and by considering its inherent requirements gives reason to why Fig. 1 must be extended and the right part of Fig. 2 will look different. In relation to genetic coding, the density of the presented information must reach a high level for signals on the cell surface, because the available space for the multitude of different messages in communication is limited. To accomplish this feat, a different class of biomolecule is required. It must be endowed with the capacity to allow the synthesis of many more isomers ('words') from its structural units (the third alphabet of life) than nucleotides or amino acids permit. As highlighted in Fig. 2, monosaccharides are ideal for this task, a fundamental insight that opened the door "to one of the last great frontiers of biochemistry" (Hart 1992; Cook 1995). The presence of chemically equivalent hydroxyl groups facilitates formation of the glycosidic bond via various linkages that then will bridge monosaccharides from the anomeric 


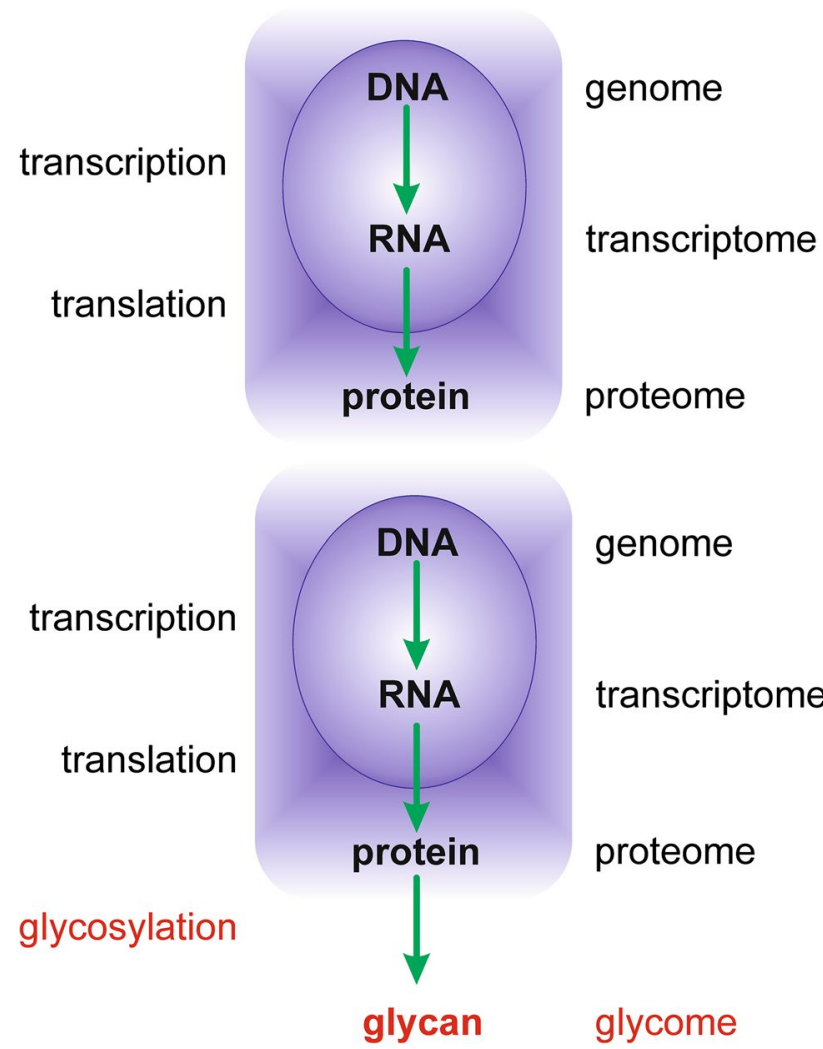

Fig. 1 Concept of the flow of biological information was initially confined to the realm of the genetic code (top). The growing realization of the functional significance of glycans as platform for the sugar code accounts for adding carbohydrate-based coding to the scheme (bottom); (from Kaltner and Gabius 2012, with permission)

center of one unit to the hydroxyl groups at $\mathrm{C} 1, \mathrm{C} 2, \mathrm{C} 3$, $\mathrm{C} 4$ or $\mathrm{C} 6$ of the next furanose(f)/pyranose( $p$ ) (Fig. 2c). Although the linkage chemistry is the same, a large set of isomers of dimers (disaccharides) can be generated, in contrast to only one dimer as is the case for nucleic acids and peptides. Additional diversity by branching can occur, yielding "compact units with explicit informational properties" (Winterburn and Phelps 1972). Hence, monosaccharides surpass nucleotides or amino acids in coding capacity and, as a consequence, the glycome is very complex (Laine 1997; Rüdiger and Gabius 2009). Accordingly, the paradigm of the flow of biological information needed to be amended by adding glycosylation/glycans (Fig. 1, bottom): DNA codes for the proteins (such as glycosyltransferases) that build the glycans from the letters of the third alphabet of life, i.e. monosaccharides. Glycans are present ubiquitously on proteins and sphingolipids. With the contributions to the first part of this special issue, principles of protein and lipid glycosylation are depicted and illustrated by instructive examples of how glycan synthesis shapes distinct aspects of cellular (re)activity (Reuter and Gabius 1999; Kopitz 2009; Zuber and Roth 2009; Corfield and Berry 2015; Gabius 2015; Hennet and Cabalzar 2015; Ledeen and Wu 2015).

\section{Glycans in information coding}

Since a substantial part of the genome is represented by genes that code for proteins involved in carbohydrate synthesis, activation and transport as well as glycan assembly, modification, remodeling and degradation, it is tempting to assume a physiological significance of the oligosaccharides. By analyzing the deviations from the normal status in diseases, ample support for this notion has been and is being gained (Gahmberg and Tolvanen 1996; Haltiwanger and Lowe 2004; Vogt et al. 2007; Honke and Taniguchi 2009; Moremen et al. 2012; Hennet and Cabalzar 2015). It is thus imperative to look into the details of the assembly lines for glycans present on both proteins and lipids (Corfield 2017; Kopitz 2017). Product analysis benefits from the enormous technical progress in glycan separation and structural characterization (Lee 2009; Nishimura 2011; Clerc et al. 2016; Song et al. 2016). When covalently linked to their scaffold, the glycans are not hidden but rather accessible. For instance, glycans can reach away for about $3 \mathrm{~nm}$ from the core linkage on the protein. On the level of cells, the glycans are thus major components and determinants for contact (a)

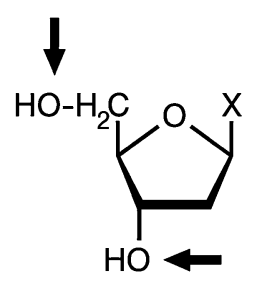

Fig. 2 Illustration of the linkage points of oligomer formation of nucleic acids (a), proteins (b) and glycans (c). In contrast to the letters of the first and second alphabets of life, each carbohydrate unit (b)

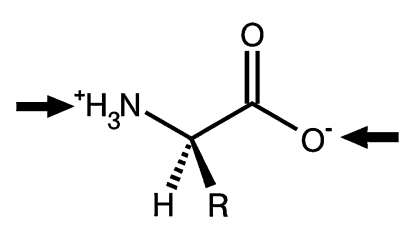

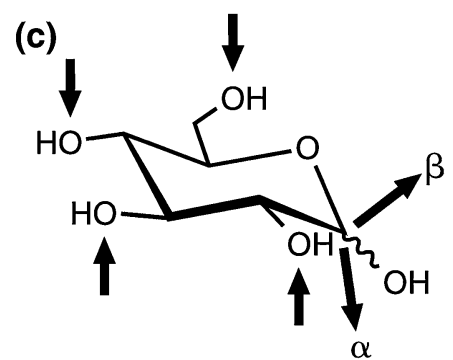

can engage any hydroxyl group for letting a chain grow or introduce branches, and the configuration at the anomeric center can vary (from Rüdiger and Gabius 2009, with permission) 


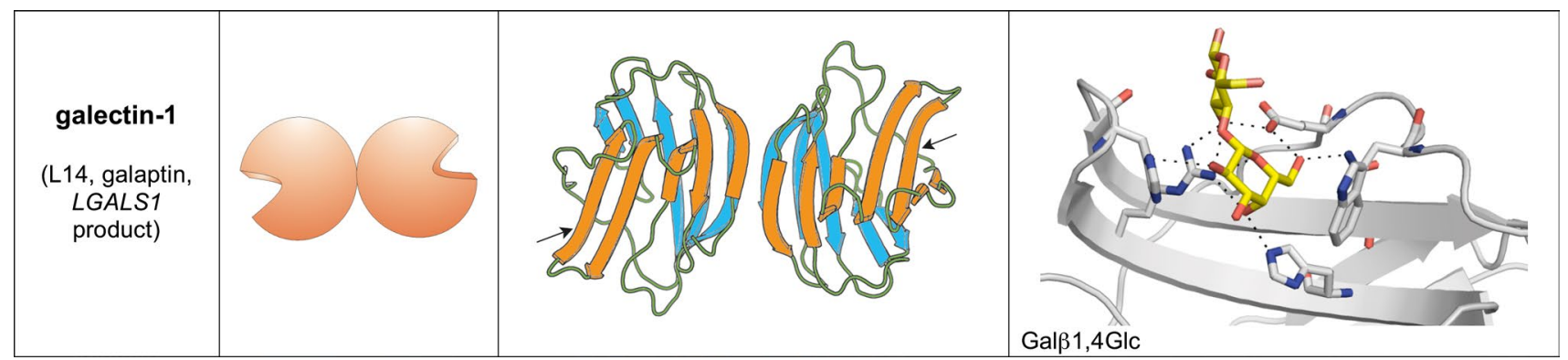

Fig. 3 Illustration of homodimeric galectin- 1 as scheme and $\beta$-sandwich protein as well as the binding profile of the disaccharide ligand lactose (from Gabius 2015, with permission)

building, and they contribute markedly to the composition of the extracellular matrix. It thus comes as no surprise that infections can start by exploiting glycans as docking sites for bacteria and viruses (Holgersson et al. 2009; van Breedam et al. 2014; Tan et al. 2015). That individual sugar moieties count enormously as surface determinants is illustrated by histo-blood group typing or by disclosing glycan-dependent routes of cell-cell adhesion and communication with the environment (Watkins 1999; Gabius et al. 2011, 2015). The respective work has spurred enormous progress and opened the door to discovering intricate regulation of expression and functional meaning of glycan epitopes, whose presence was initially viewed as a purely phenomenological feature with rather random (or complex) profile. The contributions to the first part of this special issue will introduce principles of glycosylation (Corfield 2017; Kopitz 2017) followed by a close examination of sialylation of $\mathrm{N}$-glycans to illustrate the finetuning of their synthesis and the functional importance of seemingly subtle changes (Bhide and Colley 2017). Through the study of these aspects, it will become clear how intriguingly programmable and inherently dynamic the glycome composition is, like a fingerprint characteristic for a certain cell.

As is the case for glycoproteins, sialic acids on glycans of gangliosides exert much more than merely a structural role (Schnaar et al. 2014; Ledeen and Wu 2015; Schengrund 2015; Kopitz 2017). Their involvement in binding of bacterial toxins has already become textbook knowledge. Dynamic remodeling of these glycans by enzymatic removal of a sialic acid, similarly operative for glycoproteins, is a functionally powerful means to alter the display of glycan-based signals without need for neosynthesis (Gabius et al. 2016). A formerly cryptic recognition marker is hereby made accessible as response to a distinct signal and 'read' by a tissue receptor, e.g., cell activation in the communication between regulatory and effector $\mathrm{T}$ cells [as reviewed in Kaltner et al. (2017)].
The precision of this selection process had already been noticed in the classical work on blood group specificity. The obvious capacity of phytohaemagglutinins of selecting ('reading') distinct (sugar) epitopes on the erythrocyte surface led W. C. Boyd to propose "the word lectin from Latin lectus, the past principle of legere meaning to pick, choose or select" for such proteins, different in structure from sugar-specific antibodies (Boyd 1954). The contributions to the second part of this special issue will first introduce the reader to principles of lectin structure and applications of lectins in cyto- and histochemistry. Special emphasis will then be given to informative case studies of distinct families with general significance and on the functional pairing of mammalian lectins with glycans (counterreceptors). An original article will finally describe a histochemical assay for evaluating inhibitory capacity of synthetic glycoclusters on binding of human lectins to tissue sections, a structural context displaying the glycome complexity of the physiological situation. This contribution shows how lectin histochemistry and synthetic carbohydrate chemistry team up to trace spatial characteristics of lectin binding.

\section{Lectins in information decoding}

Plant and animal lectins are a class of carbohydrate-binding proteins distinct from antibodies, enzymes and transport proteins for free mono-, di- and oligosaccharides (for details on definition and applications, see Manning et al. 2017). On the grounds of the concept of the sugar code, a large number of lectins is predicted. The existence of more than a dozen folds for proteins falling into this category attests that diversity of glycans is matched on the level of lectins [see Galleries of Lectins for animal and human lectins in Solís et al. (2015) and for plant and fungal lectins in Manning et al. (2017)]. An example for protein folding and the accommodation of the ligand for a human lectin is given in Fig. 3, with a scheme depicting its capacity to 
Table 1 Structural and spatial properties for regulating affinity and selectivity of glycan/glycoconjugate binding to lectins

\begin{tabular}{lc}
\hline Glycan/glycoconjugate & Lectin \\
\hline $\begin{array}{l}\text { Sequence and shape of the reactive epitope (mono- to oligosaccharide } \\
\text { incl. branching and substitutions) }\end{array}$ & $\begin{array}{c}\text { Architecture of the contact site for the cognate glycan(s) in the carbohy- } \\
\text { drate recognition domain (CRD) }\end{array}$ \\
$\begin{array}{l}\text { Cluster effect of multivalent glycan by } N \text { - } / O \text {-glycan branching or local } \\
\text { density variations of neighboring glycans in a glycoprotein such as }\end{array}$ & $\begin{array}{c}\text { Modular organization of CRDs in (monomeric) bi- to oligovalent lectins } \\
\text { a mucin }\end{array}$ \\
$\begin{array}{l}\text { Cluster effect by non-covalent aggregation of glycoconjugates in } \\
\text { microdomains }\end{array}$ & $\begin{array}{c}\text { Non-covalent association of a monomeric lectin into di- to oligomeric } \\
\text { aggregates }\end{array}$ \\
\hline
\end{tabular}

cross-link counterreceptors. Effectively, cross-linking glycoprotein targets such as the $\alpha_{5} \beta_{1}$-integrin (fibronectin receptor) can initiate signaling, for instance resulting in the caspase-8-dependent induction of anoikis in carcinoma cells (Amano et al. 2012). Looking at ligand binding, functional pairing with a glycan can be taken to the level to reach specificity among the complexity of cellular glycoconjugates, assigning a family member to a particular mission. As summarized in Table 1, structural and topological factors on both sides cooperate toward this end. Of note in this context, a certain glycan can well be the target of lectins from different families (Gabius et al. 2016). As a general theme for the functional pairing, not a single protein but homologous members of a family are present to 'read' signals. Starting from an ancestral gene, which gives rise to a distinct fold that is the platform for the contact site of glycans, gene duplication and sequence diversification account for group building (Gready and Zelensky 2009).

The contributions to the second part of this special issue will first introduce the principles of lectin structure and applications of lectins in cyto- and histochemistry (Manning et al. 2017). Special emphasis will then be given to informative case studies on two lectin families, i.e., C-type lectins (Mayer et al. 2017) and galectins (Kaltner et al. 2017) in animals and man, to exemplify the resulting acquisition of related but distinct properties on the structural and functional levels and on the functional pairing of mammalian lectins with glycans (counterreceptors). The intricate relation between sugar coding and quality control/intracellular routing of glycoproteins will be described next (Roth and Zuber 2017). Mutual lectin/glycoconjugate recognition is also the basis for the specificity of (ga)lectin-mediated delivery of distinct glycoproteins to axonal segments as shown in Fig. 4 (Velasco et al. 2013), one of the cases of functionality of the sugar code in neuroscience (Higuero et al. 2017).

In general, the ability of lectins to home in on certain glycans and even distinct glycoconjugates makes them valuable tools for their detection. Using labeled lectins, a glycoprofiling of cells and tissues is thus feasible (Roth 1978, 2011), as documented in Manning et al. (2017). Within this recognition process, topological factors play a role in determining the avidity and selectivity of lectin binding, on the level of glycoconjugates and their arrangement in clusters (microdomains). Synthetic glycoclusters are potent tools to delineate such structure-activity relationships (Murphy et al. 2013; Roy et al. 2016). Testing their inhibitory potency on lectin binding in tissue sections can provide information on the natural susceptibility of lectin binding in a context of glycan presentation, with potential for guiding the design of inhibitors, as recently tested for plant lectins (André et al. 2016) and for mammalian galectins (Roy et al. 2017).

\section{Conclusion}

Mechanisms of cellular communication must necessarily use biochemical signals of high coding capacity. As consequence, cells must be equipped with the respective enzymatic machinery, which must be spatially organized to guarantee ordered glycan assembly with the possibility for dynamic switches between glycan structures, a complex process assigned to the cisternal organization of the Golgi apparatus (Roth and Berger 1982; Tartakoff and Vassalli 1983; Roth et al. 1985, 1986; Roth 1987; Velasco et al. 1993; Rabouille et al. 1995; Berger and Roth 1997; Colley 1997; Pavelka 1997; Roth 2002; Shorter and Warren 2002). The implementation of context-dependent variability of products will fulfill the prerequisite to respond to changes in gene expression or of the microenvironment appropriately and swiftly. The special chemical features of monosaccharides to generate unsurpassed structural diversity and the ubiquitous presence of glycans are obvious hints that complex carbohydrates are active players in biocommunication. However, to prove that their "functions pervade biology at all levels" (Hart 2013) was not possible without major advances in glycan analysis and synthesis as well as the realization that lectins are much more than plant-derived tools for cell typing. Strategically combined work on the structurally most complex 'signals' (glycans), the 'translators' of glycan-encoded information (lectins) and their interplay has now reached the level of cracking the sugar code. Intriguingly, approaches of supramolecular chemistry to program the glycan display of surfaces of 
Fig. 4 Illustration of the presence of galectin-4 that contributes to normal axon development by delivery of glycoproteins such as L1 to axon membrane segments (green; arrowheads) (top). Reduction of sulfatide synthesis by sodium chlorate impairs routing of the lectin and perturbs axon growth (filamentous actin labeled in red, bottom). Scale bar $25 \mu \mathrm{m}$ (kindly provided by J. AbadRodríguez, Toledo, Spain; for details, please see Higuero et al., this issue)

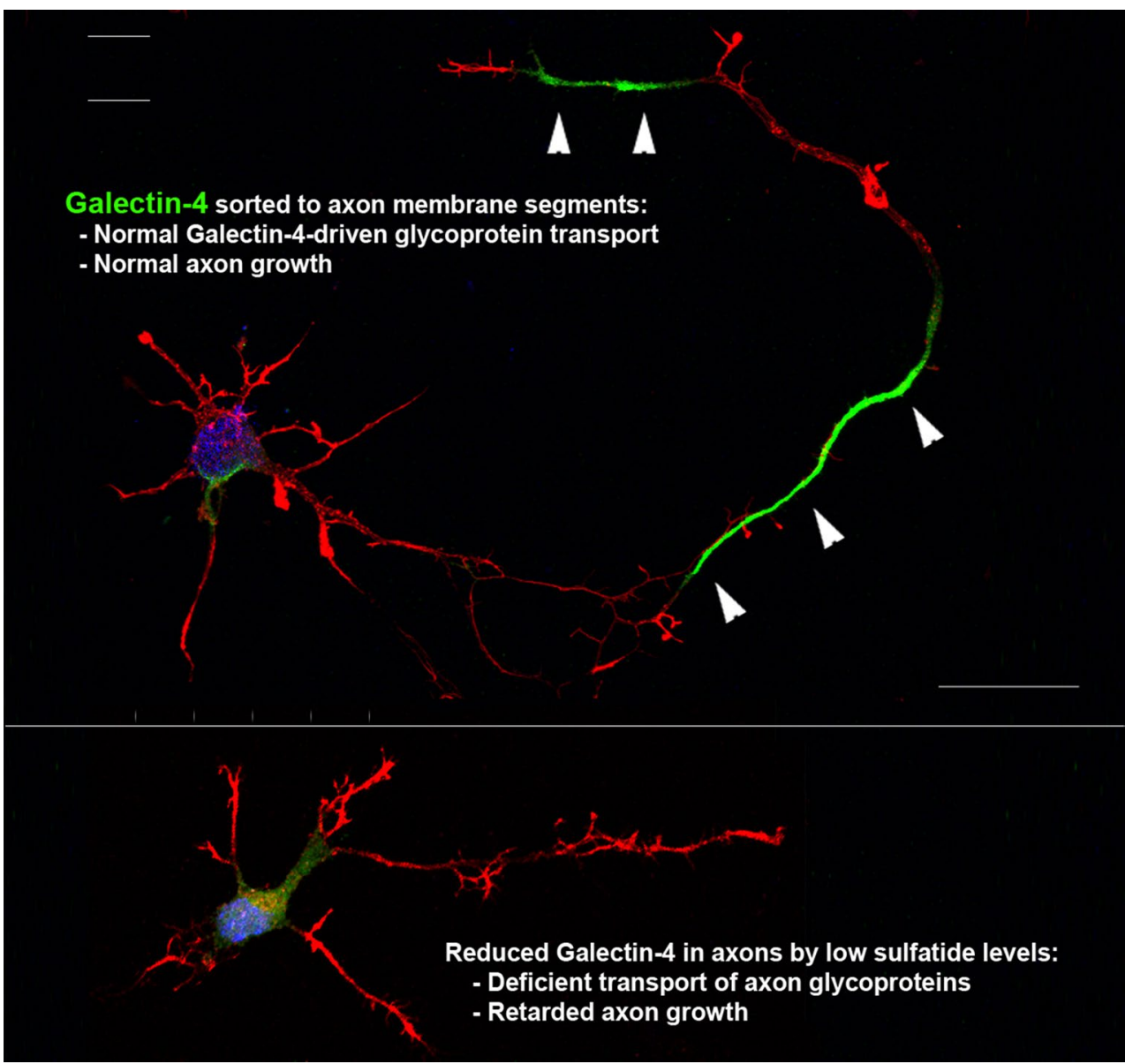

self-assembled vesicles (Percec et al. 2013; Zhang et al. 2015a; Xiao et al. 2016) or of protein engineering to rationally alter the structure of lectins (Swanson et al. 2015; Zhang et al. 2015b) make the production of test compounds possible for in-depth structure-activity investigations. Functionally oriented perusal of the glycome culminating in the identification of active counterreceptors for tissue lectins is thus the aim of functional glycomics.

\section{References}

Amano M, Eriksson H, Manning JC, Detjen KM, André S, Nishimura S-I, Lehtiö J, Gabius H-J (2012) Tumour suppressor p16 ${ }^{\mathrm{INK} 4 a}$ : anoikis-favouring decrease in N/O-glycan/cell surface sialylation by down-regulation of enzymes in sialic acid biosynthesis in tandem in a pancreatic carcinoma model. FEBS J 279:4062-4080

André S, Kaltner H, Kayser K, Murphy PV, Gabius H-J (2016) Merging carbohydrate chemistry with lectin histochemistry to study inhibition of lectin binding by glycoclusters in the natural tissue context. Histochem Cell Biol 145:185-199

Berger EG, Roth J (eds) (1997) The golgi apparatus. Birkhäuser, Basel Bhide GP, Colley KJ (2017) Sialylation of $N$-glycans: mechanism, cellular compartmentalization and function. Histochem Cell Biol 147(2). doi:10.1007/s00418-016-1520-x
Boyd WC (1954) The proteins of immune reactions. In: Neurath H, Bailey K (eds) The proteins, part 2, vol 2. Academic Press, New York, pp 756-844

Clerc F, Reiding KR, Jansen BC, Kammeijer GS, Bondt A, Wuhrer M (2016) Human plasma protein $N$-glycosylation. Glycoconj J 33:309-343

Colley KJ (1997) Golgi localization of glycosyltransferases: more questions than answers. Glycobiology 7:1-13

Cook GMW (1995) Glycobiology of the cell surface: the emergence of sugars as an important feature of the cell periphery. Glycobiology 5:449-461

Corfield AP (2017) Protein glycosylation: a primer for histochemists and cell biologists. Histochem Cell Biol 147(2). doi:10.1007/ s00418-016-1526-4

Corfield AP, Berry M (2015) Glycan variation and evolution in the eukaryotes. Trends Biochem Sci 40:351-359

Gabius H-J (2015) The magic of the sugar code. Trends Biochem Sci 40:341

Gabius H-J, André S, Jiménez-Barbero J, Romero A, Solís D (2011) From lectin structure to functional glycomics: principles of the sugar code. Trends Biochem Sci 36:298-313

Gabius H-J, Kaltner H, Kopitz J, André S (2015) The glycobiology of the CD system: a dictionary for translating marker designations into glycan/lectin structure and function. Trends Biochem Sci 40:360-376

Gabius H-J, Manning JC, Kopitz J, André S, Kaltner H (2016) Sweet complementarity: the functional pairing of glycans with lectins. Cell Mol Life Sci 73:1989-2016 
Gahmberg CG, Tolvanen M (1996) Why mammalian cell surface proteins are glycoproteins. Trends Biochem Sci 21:308-311

Gready JN, Zelensky AN (2009) Routes in lectin evolution: case study on the C-type lectin-like domains. In: Gabius H-J (ed) The sugar code. Fundamentals of glycosciences. Wiley, Weinheim, pp 329-346

Haltiwanger RS, Lowe JB (2004) Role of glycosylation in development. Annu Rev Biochem 73:491-537

Hart GW (1992) Glycosylation. Curr Opin Cell Biol 4:1017-1023

Hart GW (2013) Thematic minireview series on glycobiology and extracellular matrices: glycan functions pervade biology at all levels. J Biol Chem 288:6903

Hennet T, Cabalzar J (2015) Congenital disorders of glycosylation: a concise chart of glycocalyx dysfunction. Trends Biochem Sci 40:377-384

Higuero AM, Díez-Revuelta N, Abad-Rodríguez J (2017) The sugar code in neuronal physiology. Histochem Cell Biol 147(2). doi:10.1007/s00418-016-1519-3

Holgersson S, Gustafsson A, Gaunitz S (2009) Bacterial and viral lectins. In: Gabius H-J (ed) The sugar code. Fundamentals of glycosciences. Wiley, Weinheim, pp 279-300

Honke K, Taniguchi N (2009) Animal models to delineate glycan functionality. In: Gabius H-J (ed) The sugar code. Fundamentals of glycosciences. Wiley, Weinheim, pp 385-401

Kaltner H, Gabius H-J (2012) A toolbox of lectins for translating the sugar code: the galectin network in phylogenesis and tumors. Histol Histopathol 27:397-416

Kaltner H, Toegel S, García Caballero G, Manning JC, Ledeen RW, Gabius H-J (2017) Galectins: their network and roles in immunity/tumor growth control. Histochem Cell Biol 147(2). doi:10.1007/s00418-016-1522-8

Kopitz J (2009) Glycolipids. In: Gabius H-J (ed) The sugar code. Fundamentals of glycosciences. Wiley, Weinheim, pp 177-198

Kopitz J (2017) Lipid glycosylation: a primer for histochemists and cell biologists. Histochem Cell Biol 147(2). doi:10.1007/ s00418-016-1518-4

Laine RA (1997) The information-storing potential of the sugar code. In: Gabius H-J, Gabius S (eds) Glycosciences: status and perspectives. Chapman \& Hall, London, pp 1-14

Ledeen RW, Wu G (2015) The multi-tasked life of GM1 ganglioside, a true factotum of nature. Trends Biochem Sci 40:407-418

Lee YC (2009) Tracing the development of structural elucidation of $\mathrm{N}$-glycans. Trends Glycosci Glycotechnol 21:53-69

Manning JC, Romero A, Habermann F, García Caballero G, Kaltner H, Gabius H-J (2017) Lectins: a primer for histochemists and cell biologists. Histochem Cell Biol 147(2). doi:10.1007/ s00418-016-1524-6

Mayer S, Raulf M-K, Lepenies B (2017) C-type lectins: their network and roles in immunity/pathogen recognition. Histochem Cell Biol 147(2). doi:10.1007/s00418-016-1523-7

Moremen KW, Tiemeyer M, Nairn AV (2012) Vertebrate protein glycosylation: diversity, synthesis and function. Nat Rev Mol Cell Biol 13:448-462

Murphy PV, André S, Gabius H-J (2013) The third dimension of reading the sugar code by lectins: design of glycoclusters with cyclic scaffolds as tools with the aim to define correlations between spatial presentation and activity. Molecules 18:4026-4053

Nishimura S-I (2011) Toward automated glycan analysis. Adv Carbohydr Chem Biochem 65:219-271

Pavelka M (1997) Topology of glycosylation-a histochemist's view. In: Gabius H-J, Gabius S (eds) Glycosciences: status and perspectives. Chapman \& Hall, London, pp 115-120

Percec V, Leowanawat P, Sun HJ, Kulikov O, Nusbaum CD, Tran TM, Bertin A, Wilson DA, Peterca M, Zhang S, Kamat NP, Vargo K, Moock D, Johnston ED, Hammer DA, Pochan DJ, Chen Y, Chabre YM, Shiao TC, Bergeron-Brlek M, André S, Roy R, Gabius
H-J, Heiney PA (2013) Modular synthesis of amphiphilic Janus glycodendrimers and their self-assembly into glycodendrimersomes and other complex architectures with bioactivity to biomedically relevant lectins. J Am Chem Soc 135:9055-9077

Rabouille C, Hui N, Hunte F, Kieckbusch R, Berger EG, Warren G, Nilsson T (1995) Mapping the distribution of Golgi enzymes involved in the construction of complex oligosaccharides. J Cell Sci 108:1617-1627

Reuter G, Gabius H-J (1999) Eukaryotic glycosylation: whim of nature or multipurpose tool? Cell Mol Life Sci 55:368-422

Roth J (1978) The lectins: molecular probes in cell biology and membrane research. Exp Pathol 3(Suppl 1):1-186

Roth J (1987) Subcellular organization of glycosylation in mammalian cells. Biochim Biophys Acta 906:405-436

Roth J (2002) Protein $N$-glycosylation along the secretory pathway: relationship to organelle topography and function, protein quality control, and cell interactions. Chem Rev 102:285-303

Roth J (2011) Lectins for histochemical demonstration of glycans. Histochem Cell Biol 136:117-130

Roth J, Berger EG (1982) Immunocytochemical localization of galactosyltransferase in HeLa cells: codistribution with thiamine pyrophosphatase in trans-Golgi cisternae. J Cell Biol 93:223-229

Roth J, Zuber C (2017) Quality control of glycoprotein folding and ERAD: the role of $N$-glycan handling, EDEM1 and OS-9. Histochem Cell Biol 147(2). doi:10.1007/s00418-016-1513-9

Roth J, Taatjes DJ, Lucocq JM, Weinstein J, Paulson JC (1985) Demonstration of an extensive trans-tubular network continuous with the Golgi apparatus stack that may function in glycosylation. Cell 43:287-295

Roth J, Taatjes DJ, Weinstein J, Paulson JC, Greenwell P, Watkins WM (1986) Differential subcompartmentation of terminal glycosylation in the Golgi apparatus of intestinal absorptive and goblet cells. J Biol Chem 261:14307-14312

Roy R, Murphy PV, Gabius H-J (2016) Multivalent carbohydrate-lectin interactions: how synthetic chemistry enables insights into nanometric recognition. Molecules 21:629

Roy R, Cao Y, Kaltner H, Kottari N, Shiao TC, Belkhadem K, André S, Manning JC, Murphy PV, Gabius H-J (2017) Teaming up synthetic chemistry and histochemistry for activity screening in galectin-directed inhibitor design. Histochem Cell Biol 147(2). doi:10.1007/s00418-016-1525-5

Rüdiger H, Gabius H-J (2009) The biochemical basis and coding capacity of the sugar code. In: Gabius H-J (ed) The sugar code. Fundamentals of glycosciences. Wiley, Weinheim, pp 3-13

Schengrund C-L (2015) Gangliosides: glycosphingolipids essential for normal neural development and function. Trends Biochem Sci 40:397-406

Schnaar RL, Gerardy-Schahn R, Hildebrandt H (2014) Sialic acids in the brain: gangliosides and polysialic acid in nervous system development, stability, disease, and regeneration. Physiol Rev 94:461-518

Shorter J, Warren G (2002) Golgi architecture and inheritance. Annu Rev Cell Dev Biol 18:379-420

Solís D, Bovin NV, Davis AP, Jiménez-Barbero J, Romero A, Roy R, Smetana K Jr, Gabius H-J (2015) A guide into glycosciences: how chemistry, biochemistry and biology cooperate to crack the sugar code. Biochim Biophys Acta 1850:186-235

Song X, Ju H, Lasanajak Y, Kudelka MR, Smith DF, Cummings RD (2016) Oxidative release of natural glycans for functional glycomics. Nat Methods 13:528-534

Swanson MD, Boudreaux DM, Salmon L, Chugh J, Winter HC, Meagher JL, André S, Murphy PV, Oscarson S, Roy R, King S, Kaplan MH, Goldstein IJ, Tarbet EB, Hurst BL, Smee DF, de la Fuente C, Hoffmann HH, Xue Y, Rice CM, Schols D, García JV, Stuckey JA, Gabius H-J, Al-Hashimi HM, Markovitz DM (2015) 
Engineering a therapeutic lectin by uncoupling mitogenicity from antiviral activity. Cell 163:746-758

Tan FY, Tang CM, Exley RM (2015) Sugar coating: bacterial protein glycosylation and host-microbe interactions. Trends Biochem Sci 40:342-350

Tartakoff AM, Vassalli P (1983) Lectin-binding sites as markers of Golgi subcompartments: proximal-to-distal maturation of oligosaccharides. J Cell Biol 97:1243-1248

van Breedam W, Pohlmann S, Favoreel HW, de Groot RJ, Nauwynck HJ (2014) Bitter-sweet symphony: glycan-lectin interactions in virus biology. FEMS Microbiol Rev 38:598-632

Velasco A, Hendricks L, Moremen KW, Tulsiani DR, Touster O, Farquhar MG (1993) Cell type-dependent variations in the subcellular distribution of $\alpha$-mannosidase I and II. J Cell Biol 122:39-51

Velasco S, Díez-Revuelta N, Hernández-Iglesias T, Kaltner H, André S, Gabius H-J, Abad-Rodríguez J (2013) Neuronal galectin-4 is required for axon growth and for the organization of axonal membrane L1 delivery and clustering. J Neurochem 125:49-62

Vogt G, Vogt B, Chuzhanova N, Julenius K, Cooper DN, Casanova JL (2007) Gain-of-glycosylation mutations. Curr Opin Genet Dev 17:245-251

Watkins WM (1999) A half century of blood-group antigen research: some personal recollections. Trends Glycosci Glycotechnol $11: 391-411$
Winterburn PJ, Phelps CF (1972) The significance of glycosylated proteins. Nature 236:147-151

Xiao Q, Zhang S, Wang Z, Sherman SE, Moussodia RO, Peterca M, Muncan A, Williams DR, Hammer DA, Vértesy S, André S, Gabius H-J, Klein ML, Percec V (2016) Onion-like glycodendrimersomes from sequence-defined Janus glycodendrimers and influence of architecture on reactivity to a lectin. Proc Natl Acad Sci USA 113:1162-1167

Zhang S, Moussodia R-O, Vértesy S, André S, Klein ML, Gabius H-J, Percec V (2015a) Unraveling functional significance of natural variations of a human galectin by glycodendrimersomes with programmable glycan surface. Proc Natl Acad Sci USA 112:5585-5590

Zhang S, Moussodia R-O, Murzeau C, Sun HJ, Klein ML, Vértesy S, André S, Roy R, Gabius H-J, Percec V (2015b) Dissecting molecular aspects of cell interactions using glycodendrimersomes with programmable glycan presentation and engineered human lectins. Angew Chem Int Ed 54:4036-4040

Zuber C, Roth J (2009) N-Glycosylation. In: Gabius H-J (ed) The sugar code. Fundamentals of glycosciences. Wiley, Weinheim, pp 87-110 